ORIGINAL ARTICLE

\title{
PENGETAHUAN DAN PENGGUNAAN OBAT ANALGESIK DAN ANTIPIRETIK PADA IBU HAMIL
}

\author{
A. A. Rai Mas Feby Kumala Dewi, Aina Senja Yuliyani, Bella Rizkia Dianita, Diah Ayu Wakita \\ Trimanda, Febria Tri Erliana, Helmy Kurniawan, Muhammad Zaesal Rizki Muzaffar, Rossika \\ Rachmafebri, Sakinah, Vidya Annisa Pebriastika, Yunita Nita \\ Departemen Farmasi Komunitas, Fakultas Farmasi, Universitas Airlangga \\ Gedung Nanizar Zaman Joenoes Kampus C, Jl. Ir. Soekarno, Surabaya 60115, Indonesia \\ E-mail: yunitanita@ff.unair.ac.id
}

\begin{abstract}
ABSTRAK
Pada saat kehamilan terjadi beberapa keluhan salah satunya adalah nyeri. Nyeri selama kehamilan baik yang disebabkan oleh kehamilan ataupun keadaan akut perlu ditangani secara memadai. Berbagai analgesik dan antipiretik diresepkan untuk mengobati rasa sakit pada ibu hamil. Tujuan penelitian ini untuk mengetahui tentang pengetahuan, penggunaan, dan pengaruh usia serta hubungan pendidikan dengan pengetahuan ibu hamil terhadap obat analgesik dan antipiretik pada ibu hamil. Penelitian dilakukan secara cross sectional di wilayah Surabaya Timur di beberapa puskesmas dan praktik bidan swasta pada tanggal 11-14 September 2019. Metode sampling yang digunakan adalah purposive sampling. Instrumen yang digunakan adalah kuesioner. Sampel penelitian adalah ibu hamil yang memenuhi kriteria inklusi. Variabel bebas dalam penelitian adalah umur dan pendidikan, serta variabel terikat adalah pengetahuan tentang penggunaan analgesik dan antipiretik. Pada hasil pengetahuan, diperoleh total skor rata-rata 6,3 yang tergolong sebagai tingkat pengetahuan sedang dan hasil penggunaan obat analgesik dan antipiretik pada ibu hamil sudah dipahami dengan baik. Berdasarkan uji ANOVA diperoleh p-value $>\alpha$ sebesar $(0,373>0,05)$ dan uji Fisher diperoleh p-value $>\alpha$ sebesar $(0,469>0,05)$. Sehingga, variabel usia dan variabel pendidikan tidak berpengaruh terhadap variabel pengetahuan ibu hamil tentang obat analgesik dan antipiretik selama kehamilan.
\end{abstract}

Kata Kunci: kehamilan, ibu hamil, nyeri, analgesik dan antipiretik

\begin{abstract}
There are several complaints during pregnancy, one of them is pain. Pain during pregnancy caused by pregnancy or acute conditions need to be treated adequately. Various analgesics and antipyretics are prescribed to treat pain in pregnant women. This study aimed to determine knowledge, use, and influence of age as well as relationship between education and knowledge of pregnant women on analgesic and antipyretic drugs in pregnant women. Study was conducted cross sectionally in East Surabaya area in several puskesmas and private midwife practice places on 11-14 September 2019. Sampling method used was purposive sampling. Instrument used was a questionnaire. Sample in this study were pregnant women who met the inclusion criteria, namely pregnant women and patients from puskesmas and private midwives in East Surabaya. Independent variables in this study are age and education, while dependent variable in this study is knowledge about use of analgesics and antipyretics. Results of knowledge with a total score of 6.3 classified as moderate level of knowledge and use of analgesic and antipyretic drugs in pregnant women are well understood. Based on ANOVA test, it was obtained p-value $>\alpha$ of $(0.373>0.05)$ and Fisher's test obtained p-value $>\alpha$ of $(0.469>0.05)$. It can be concluded that, age variable and educational variable did not affect variable knowledge of pregnant women about analgesic and antipyretic drugs during pregnancy.
\end{abstract}

Key words: pregnancy, pregnant women, pain, analgesics and antipyretics 


\section{PENDAHULUAN}

Kehamilan membutuhkan waktu 9 bulan yang dibagi dalam tiga periode yaitu trimester I, trimester II, dan trimester III. Trimester I adalah kehamilan pada minggu pertama hingga minggu ke-13. Trimester II terhitung mulai dari minggu ke-14 sampai minggu ke-26. Sedangkan untuk trimester III dihitung mulai dari minggu ke-27 sampai minggu ke-38 atau 40 yang merupakan akhir dari kehamilan (Susanti, 2008).

Pada kehamilan sering terjadi beberapa keluhan, meskipun keluhan ini umum terjadi. Tetapi hal ini tidak dialami oleh semua wanita yang sedang mengandung, karena terdapat wanita hamil yang tidak mengalami keluhan sama sekali. Berikut contoh keluhan yang sering dialami ibu hamil seperti konstipasi, batuk, diare, hemoroid (ambeien), alergi, sakit perut, nyeri (sakit kepala, sakit gigi) dan keputihan (Byrom et al., 2009).

Nyeri selama kehamilan yang disebabkan oleh kehamilan atau situasi akut seperti cedera, infeksi atau yang mendasari gangguan medis seperti rheumatoid arthritis, perlu dikelola secara memadai. Rasa sakit yang memberi pengaruh fisik dan kesejahteraan psikologis wanita hamil dapat menyebabkan depresi dan kecemasan. Di Provinsi Jawa Timur diperkirakan sekitar $65 \%$ ibu hamil masih mengalami back pain (Mafikasari dan Kartikasari, 2015).

Selain nyeri, suhu tubuh $>38^{0} \mathrm{C}$ sering terjadi pada kehamilan yang dapat didefinisikan sebagai demam. Penyebab dan konsekuensi demam bervariasi tergantung pada waktu kejadian (masa kehamilan, persalinan atau periode postnatal). Bahkan jika demam bukan disebabkan karena infeksi, pengenalan dini penyakit menular wajib diketahui konsekuensinya pada ibu dan janin (Le Gouez et al., 2016). Demam semasa kehamilan dapat membahayakan perkembangan janin dan dapat menyebabkan risiko cacat pada janin. Pada studi yang dilakukan di Denmark kepada 100.418 wanita hamil, menunjukkan bahwa 8.321 wanita melaporkan demam selama trimester pertama $(10,8 \%)$ dan 2.876 bayi didiagnosis dengan kelainan bawaan $(3,7 \%)$ (Sass et al., 2017).

Berbagai obat analgesik dan antipiretik diresepkan untuk mengobati rasa sakit pada ibu hamil. Obat-obatan analgesik dan antipiretik tersedia dalam golongan bebas dan bebas terbatas yang dapat dibeli tanpa resep serta golongan keras yang dapat dibeli hanya dengan resep dokter. Obat tersebut digunakan untuk mengobati rasa sakit seperti sakit kepala, nyeri, radang sendi, dan demam. Menurut dua studi di
Amerika Serikat menunjukan bahwa sekitar 65$70 \%$ wanita hamil menggunakan asetaminofen, yaitu obat antipiretik dan analgesik selama kehamilan (FDA, 2015). Oleh karena itu, wanita dan tenaga kesehatan perlu memahami keamanan analgesik dan risiko mengobati dengan tidak menimbulkan rasa sakit selama kehamilan dan menyusui. Risiko latar belakang utama cacat pada kehamilan adalah $3 \%$. Perempuan dan tenaga kesehatan sepatutnya memberi informasi mengenai risiko pemakaian obat (Malhotra dan Khanna, 2016).

Tujuan penelitian ini untuk mengetahui tentang pengetahuan, penggunaan, dan pengaruh usia serta hubungan pendidikan dengan pengetahuan ibu hamil terhadap obat analgesik dan antipiretik pada ibu hamil.

\section{METODE PENELITIAN}

Penelitian ini dilakukan secara cross sectional di wilayah Surabaya Timur pada beberapa puskesmas yang dapat dilihat pada tabel 1 dan tempat praktek bidan swasta.

Tabel 1. Daftar puskesmas wilayah Surabaya Timur tempat pengambilan data pengetahuan dan penggunaan obat analgesik dan antipiretik pada ibu hamil

\begin{tabular}{ll}
\hline \hline No. & Nama Puskesmas \\
\hline 1 & Puskesmas Gading \\
\hline 2 & Puskesmas Kalijudan \\
\hline 3 & Puskesmas Kenjeran \\
\hline 4 & Puskesmas Keputih \\
\hline 5 & Puskesmas Menur \\
\hline 6 & Puskesmas Mojo \\
\hline 7 & Puskesmas Mulyorejo \\
\hline 8 & Puskesmas Ngagel Rejo \\
\hline 9 & Puskesmas Pacar Keling \\
\hline 10 & Puskesmas Pucang Sewu \\
\hline
\end{tabular}

Metode sampling yang digunakan adalah purposive sampling. Sampel pada penelitian ini adalah ibu hamil yang memenuhi kriteria inklusi yakni hamil dan pasien dari puskesmas dan bidan swasta di wilayah Surabaya Timur. Jumlah responden sebanyak 100 ibu hamil. Variabel bebas dalam penelitian ini adalah umur dan pendidikan, sedangkan variabel terikat dalam penelitian ini adalah pengetahuan tentang penggunaan obat analgesik dan antipiretik.

Instrumen yang digunakan dalam penelitian ini adalah kuesioner. Kuesioner dibuat berdasarkan indikator kuesioner dengan variabel pengetahuan yang dapat dilihat pada tabel 2 dan variabel penggunaan yang dapat dilihat pada tabel 3 terkait obat analgesik dan antipiretik pada ibu hamil. Kuesioner berisi daftar pernyataan dan pertanyaan yang berkaitan 
dengan pengetahuan dan penggunaan obat analgesik dan antipiretik.

Tabel 2. Indikator kuesioner variabel pengetahuan obat analgesik dan antipiretik pada ibu hamil di puskesmas wilayah Surabaya Timur

\begin{tabular}{|c|c|}
\hline Indikator & Pernyataan \\
\hline $\begin{array}{l}\text { Efek obat } \\
\text { terhadap } \\
\text { janin }\end{array}$ & $\begin{array}{l}\text { 1. Obat anti nyeri dan anti demam } \\
\text { memberikan efek buruk pada } \\
\text { janin } \\
\text { 2. Kecacatan janin merupakan efek } \\
\text { buruk dari obat anti nyeri dan } \\
\text { anti demam }\end{array}$ \\
\hline Keamanan & $\begin{array}{l}\text { 3. Parasetamol merupakan obat } \\
\text { yang aman dikonsumsi selama } \\
\text { kehamilan } \\
\text { 4. } \\
\text { nyeri yang aman dikonsumsi } \\
\text { selama kehamilan } \\
\text { 5. Antalgin merupakan obat yang } \\
\text { aman dikonsums selama } \\
\text { kehamilan. } \\
\text { 6. Ibuprofen merupakan obat yang } \\
\text { aman dikonsums selama } \\
\text { kehamilan } \\
\text { 7. Asam mefenamat merupakan } \\
\text { obat yang aman untuk } \\
\text { dikonsumsi selama kehamilan } \\
\text { 7ramadol merupakan obat yang } \\
\text { aman dikonsumsi selama } \\
\text { kehamilan } \\
\text { 9. Penggunaan obat anti nyeri dan } \\
\text { anti demam pada dosis tinggi } \\
\text { dan penggunaan jangka lama } \\
\text { aman untuk janin } \\
\text { 10. Obat anti nyeri dengan logo } \\
\text { bertanda merah boleh digunakan } \\
\text { secara pengobatan sendiri pada } \\
\text { ibu hamil }\end{array}$ \\
\hline Indikasi & $\begin{array}{l}\text { 11. } \begin{array}{l}\text { Parasetamol mampu meredakan } \\
\text { nyeri saat kehamilan }\end{array} \\
\text { 12. } \begin{array}{l}\text { Parasetamol tidak mampu } \\
\text { menurunkan panas pada } \\
\text { kehamilan }\end{array} \\
\end{array}$ \\
\hline $\begin{array}{l}\text { Tempat } \\
\text { memperoleh }\end{array}$ & $\begin{array}{l}\text { 13. Informasi penggunaan obat anti } \\
\text { nyeri dan anti demam untuk ibu } \\
\text { hamil yang valid didapatkan di } \\
\text { minimarket / warung. }\end{array}$ \\
\hline $\begin{array}{l}\text { Aturan } \\
\text { pakai }\end{array}$ & $\begin{array}{l}\text { 14. Obat antinyeri dan anti demam } \\
\text { untuk ibu hamil harus diminum } \\
\text { sampai habis } \\
\text { 15. Obat anti nyeri dan anti demam } \\
\text { digunakan harus tiga kali sehari }\end{array}$ \\
\hline
\end{tabular}

Selanjutnya seluruh instrumen tersebut dilaksanakan uji validitas rupa dan isi. Uji validitas dilakukan pada ibu yang pernah hamil di daerah Kampus B Universitas Airlangga. Uji dilakukan dengan meminta responden mengisi kuesioner dan menyampaikan saran serta kritik terkait kuesioner.
Tabel 3. Indikator kuesioner variabel penggunaan obat analgesik dan antipiretik pada ibu hamil di puskesmas wilayah Surabaya Timur

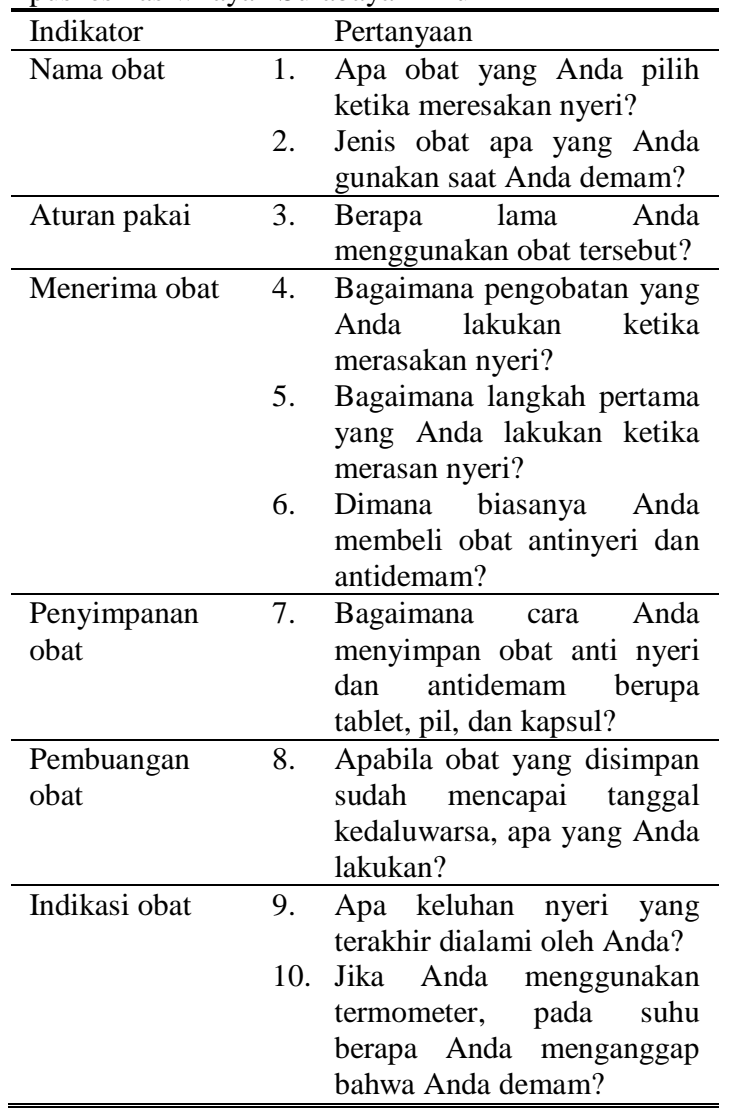

Hasil dari uji validitas yakni perlu adanya perbaikan beberapa pernyataan yang bahasanya kurang tepat pada kuesioner pengetahuan.

Analisis data pengetahuan dilakukan dengan perhitungan skor benar diberi nilai skor 1 dan skor salah serta tidak tahu diberi nilai skor 0 . Hasil analisis data pengetahuan yang berupa total skor kuesioner tersebut dikategorikan dalam beberapa tingkat pengetahuan, yaitu tingkat pengetahuan rendah dengan total skor 03 , tingkat pengetahuan sedang dengan total skor 4-7, tingkat pengetahuan tinggi dengan total skor sedang dan tingkat pengetahuan sangat tinggi dengan total skor 12-15. Analisis data penggunaan dilakukan secara deskriptif dengan mendeskripsikan penggunaan responden terhadap obat analgesik dan antipiretik pada ibu hamil.

Analisis regresi linier dilakukan untuk mengetahui apakah antara variabel bebas (X) dan variabel terikat (Y) mempunyai hubungan linier dan mengukur hubungan tersebut dengan memprediksi nilai signifikan (Walpole et al., 2012). Dalam penelitian ini, regresi linier digunakan untuk mengkaji hubungan antara satu variabel $(\mathrm{X})$ yaitu usia dengan variabel $(\mathrm{Y})$ yaitu skor pengetahuan. 
Uji eksak Fisher digunakan untuk menguji taraf signifikasi hipotesis komparatif dua sampel independen, selain itu juga untuk mengetahui apakah ada perlakuan yang berbeda dari dua populasi yang di uji (Payadnya dan Jayantika, 2018). Dalam penelitian ini, uji eksak Fisher digunakan untuk mengkaji hubungan variabel pendidikan dengan variabel skor pengetahuan. Hipotesis $0\left(\mathrm{H}_{0}\right)$ akan ditolak bila $\mathrm{p}<0,05$.

\section{HASIL DAN PEMBAHASAN}

\section{Data Demografi}

Data demografi meliputi usia dan pendidikan dari ibu hamil. Dari data yang diisi oleh 100 responden, usia responden ibu hamil terbanyak adalah sekitar 26-30 tahun sebanyak 44 responden dan pendidikan terakhir responden terbanyak adalah SMA/SMK yakni sebanyak 47 responden yang dapat dilihat pada tabel 4.

Tabel 4. Demografi responden ibu hamil di puskesmas wilayah Surabaya Timur

\begin{tabular}{ccc}
\hline \hline Indikator & $\begin{array}{c}\text { Demografi } \\
\text { Responden }\end{array}$ & $\mathrm{n}(\%)$ \\
\hline Usia & $\leq 20$ & $3(3 \%)$ \\
& $21-25$ & $27(27 \%)$ \\
& $26-30$ & $44(44 \%)$ \\
& $31-35$ & $13(13 \%)$ \\
Pendidikan & SD & $6(13 \%)$ \\
Terakhir & SMP & $13(13 \%)$ \\
& SMA/SMK & $47(47 \%)$ \\
& D1/D3/S1/S2 & $34(34 \%)$ \\
\hline \hline
\end{tabular}

\section{Pengetahuan Obat Analgesik dan Antipiretik} Pada Ibu Hamil

Skor kuesioner menunjukkan tingkat pengetahuan ibu hamil terkait efek obat terhadap janin, keamanan, indikasi, tempat memperoleh dan aturan pakai obat analgesik dan antipiretik. Pada tabel 5 menunjukkan banyak ibu hamil masih kurang pengetahuan tentang nama-nama obat yang aman dikonsumsi selama kehamilan, khususnya obat aspirin hanya memiliki persentase jawaban benar sebesar $24 \%(n=24)$. Aspirin merupakan obat yang digolongkan tidak aman dikonsumsi oleh ibu hamil yaitu masuk kategori kehamilan C (trimester 1, 2), D (trimester 3). Aspirin dapat menyebabkan kegagalan fungsi dan risiko hemoragi, menunda persalinan dan memperlama proses persalinan dengan peningkatan risiko pendarahan. Dosis analgesik pada minggu-minggu terakhir sebaiknya dihindari (dosis rendah mungkin tidak berbahaya). Pada dosis tinggi, terjadi penutupan ductus arterious janin dengan kemungkinan timbul hipertensi paru yang menetap pada bayi (BPOM, 2017).

Tabel 5. Hasil pengetahuan tentang obat analgesik dan antipiretik pada ibu hamil di puskesmas wilayah Surabaya Timur

\begin{tabular}{|c|c|c|}
\hline Variabel Pengetahuan & Benar & $\mathrm{n}(\%)$ \\
\hline $\begin{array}{l}\text { Obat anti nyeri dan anti } \\
\text { demam memberikan efek } \\
\text { buruk pada janin }\end{array}$ & 30 & $30(30 \%)$ \\
\hline $\begin{array}{l}\text { Kecacatan janin merupakan } \\
\text { efek buruk dari obat anti } \\
\text { nyeri dan anti demam }\end{array}$ & 26 & $26(26 \%)$ \\
\hline $\begin{array}{l}\text { Parasetamol merupakan } \\
\text { obat yang aman dikonsumsi } \\
\text { selama kehamilan }\end{array}$ & 49 & $49(49 \%)$ \\
\hline \begin{tabular}{lr}
\multicolumn{3}{l}{ Aspirin merupakan obat anti } \\
nyeri yang aman \\
dikonsumsi \\
kehamilan
\end{tabular} & 24 & $24(24 \%)$ \\
\hline $\begin{array}{l}\text { Antalgin merupakan obat } \\
\text { yang aman dikonsumsi } \\
\text { selama kehamilan }\end{array}$ & 36 & $36(36 \%)$ \\
\hline $\begin{array}{l}\text { Ibuprofen merupakan obat } \\
\text { yang aman dikonsumsi } \\
\text { selama kehamilan }\end{array}$ & 30 & $30(30 \%)$ \\
\hline $\begin{array}{l}\text { Asam mefenamat } \\
\text { merupakan obat yang aman } \\
\text { untuk dikonsumsi selama } \\
\text { kehamilan }\end{array}$ & 27 & $27(27 \%)$ \\
\hline $\begin{array}{l}\text { Tramadol merupakan obat } \\
\text { yang aman dikonsumsi } \\
\text { selama kehamilan }\end{array}$ & 26 & $26(26 \%)$ \\
\hline $\begin{array}{l}\text { Penggunaan obat anti nyeri } \\
\text { dan anti demam pada dosis } \\
\text { tinggi dan penggunaan } \\
\text { jangka lama aman untuk } \\
\text { janin }\end{array}$ & 74 & $74(74 \%)$ \\
\hline $\begin{array}{l}\text { Obat anti nyeri dengan logo } \\
\text { bertanda merah boleh } \\
\text { digunakan } \\
\text { pengobatan sendiri pada ibu } \\
\text { hamil }\end{array}$ & 39 & $39(39 \%)$ \\
\hline \begin{tabular}{lrr} 
Parasetamol & \multicolumn{2}{c}{ mampu } \\
meredakan & nyeri & saat \\
kehamilan & & \\
\end{tabular} & 42 & $42(42 \%)$ \\
\hline $\begin{array}{l}\text { Parasetamol tidak mampu } \\
\text { menurunkan panas pada } \\
\text { kehamilan }\end{array}$ & 45 & $45(45 \%)$ \\
\hline $\begin{array}{l}\text { Informasi penggunaan obat } \\
\text { anti nyeri dan anti demam } \\
\text { untuk ibu hamil yang valid } \\
\text { didapatkan di minimarket/ } \\
\text { warung }\end{array}$ & 82 & $82(82 \%)$ \\
\hline $\begin{array}{l}\text { Obat anti nyeri dan anti } \\
\text { demam untuk ibu hamil } \\
\text { harus diminum sampai habis }\end{array}$ & 55 & $55(55 \%)$ \\
\hline $\begin{array}{l}\text { Obat anti nyeri dan anti } \\
\text { demam digunakan harus } \\
\text { tiga kali sehari }\end{array}$ & 45 & $45(45 \%)$ \\
\hline Rata-rata Total Skor & & 3 \\
\hline
\end{tabular}


Pada tabel 5, ibu hamil sebanyak 82 responden $(82 \%)$ sudah paham mengenai tempat memperoleh informasi penggunaan obat anti nyeri dan anti demam untuk ibu hamil yang aman selama kehamilan. Tidak benar jika bertanya pada penjual warung ataupun penjaga minimarket mengenai informasi tentang obat. Pemberian informasi obat (antinyeri dan antidemam) harus ditanyakan pada tenaga medis terutama apoteker (Menkes, 2002). Hasil rata-rata total skor pengetahuan yang diperoleh sebesar 6,3 yang dapat dilihat pada tabel 5 .

Skor tersebut menunjukkan tingkat pengetahuan ibu hamil di Wilayah Surabaya Timur berada pada range tingkat pengetahuan sedang. Hal ini sesuai dengan hasil penelitian pengetahuan mengenai penggunaan obat selama kehamilan di Puskesmas Denpasar Utara II Bali (Aprilia dan Artini, 2017) yang menyatakan sebagian besar responden mempunyai tingkat pengetahuan cukup sebanyak 57 responden (59, $4 \%$ ).

\section{Penggunaan Obat Analgesik dan Antipiretik pada Ibu Hamil}

Hasil penggunaan tentang obat analgesik dan antipiretik pada ibu hamil dapat dilihat pada tabel 6. Obat terbanyak yang dipilih oleh ibu hamil ketika merasakan nyeri dan demam adalah parasetamol dengan persentase sebanyak $32 \%(\mathrm{n}=32)$ untuk nyeri dan dengan persentase sebanyak $70 \% \quad(n=70)$ untuk demam. Parasetamol merupakan obat nyeri ringan sampai sedang nyeri sesudah operasi cabut gigi dan pireksia (BPOM RI, 2014). Obat parasetamol masuk dalam kategori B yang berarti berisiko kecil atau bahkan tidak berisiko sama sekali pada sejumlah kasus. Parasetamol aman digunakan pada semua tahap kehamilan untuk menghilangkan rasa sakit dan untuk menurunkan suhu tubuh. Dalam dosis terapeutik, parasetamol aman digunakan untuk penggunaan jangka pendek. Namun dosis harian yang terus menerus tinggi pada ibu hamil mungkin dapat menyebabkan anemia berat dan penyakit ginjal fatal pada bayinya (Briggs et al., 2015).

Ibu hamil dengan persentase 52\% $(\mathrm{n}=52)$ mengonsumsi obat antinyeri sesuai aturan pakai hingga nyeri yang dirasakan hilang. Selama masa kehamilan, ibu dan janin adalah unit fungsi yang tak terpisahkan. Obat dapat menyebabkan efek yang tidak dikehendaki pada janin selama masa kehamilan dikarenakan banyak obat yang dapat melintasi plasenta, maka penggunaan obat pada wanita hamil perlu berhati-hati (Depkes RI, 2006).
Berdasarkan tabel 6, ibu hamil banyak menggunakan parasetamol untuk meredakan nyeri yang dialami. Parasetamol umumnya dianggap sebagai analgesik pilihan pada pasien ibu hamil.

Tabel 6. Hasil penggunaan tentang obat analgesik dan antipiretik pada ibu hamil di puskesmas wilayah Surabaya Timur

\begin{tabular}{|c|c|}
\hline Indikator & $\mathrm{n}(\%)$ \\
\hline \multicolumn{2}{|l|}{ Nama Obat Nyeri } \\
\hline Parasetamol & $32(32 \%)$ \\
\hline Antalgin & $4(4 \%)$ \\
\hline Asam mefenamat & $18(18 \%)$ \\
\hline Ibuprofen & $0(0 \%)$ \\
\hline Aspirin & $0(0 \%)$ \\
\hline Obat lain & $22(22 \%)$ \\
\hline Tidak tahu & $24(24 \%)$ \\
\hline \multicolumn{2}{|l|}{ Nama Obat Demam } \\
\hline Parasetamol & $70(70 \%)$ \\
\hline Antalgin & $0(0 \%)$ \\
\hline Asam mefenamat & $0(0 \%)$ \\
\hline Ibuprofen & $4(4 \%)$ \\
\hline Aspirin & $3(3 \%)$ \\
\hline Obat lain & $8(8 \%)$ \\
\hline Tidak tahu & $15(15 \%)$ \\
\hline \multicolumn{2}{|l|}{ Aturan Pakai Obat } \\
\hline Sampai nyeri hilang & $52(52 \%)$ \\
\hline Kurang dari 3 hari & $26(26 \%)$ \\
\hline Antara 3-7 hari & $7(7 \%)$ \\
\hline Lebih dari 7 hari & $0(0 \%)$ \\
\hline Tidak tahu & $15(15 \%)$ \\
\hline \multicolumn{2}{|l|}{ Pengobatan Nyeri } \\
\hline Tanpa obat (pijat) & $20(20 \%)$ \\
\hline Membeli obat sendiri & $3(3 \%)$ \\
\hline Pergi ke rumah sakit/dokter & $49(49 \%)$ \\
\hline Membiarkan sampai sembuh & $28(28 \%)$ \\
\hline Tidak tahu & $0(0 \%)$ \\
\hline \multicolumn{2}{|l|}{ Pengobatan Demam } \\
\hline Mengompres & $21(21 \%)$ \\
\hline Membawa ke dokter & $53(53 \%)$ \\
\hline Memberi obat penurun panas & $17(17 \%)$ \\
\hline Membiarkannya sampai sembuh & $9(9 \%)$ \\
\hline Tidak tahu & $0(0 \%)$ \\
\hline \multicolumn{2}{|l|}{ Menerima Obat Nyeri dan Demam } \\
\hline Apotek & $98(98 \%)$ \\
\hline Minimarket & $1(1 \%)$ \\
\hline Warung kelontong & $0(0 \%)$ \\
\hline Toko online & $0(0 \%)$ \\
\hline Tidak tahu & $1(1 \%)$ \\
\hline \multicolumn{2}{|l|}{ Penyimpanan Obat Nyeri } \\
\hline $\begin{array}{l}\text { Disimpan di tempat yang mudah } \\
\text { dijangkau anak-anak }\end{array}$ & $5(5 \%)$ \\
\hline $\begin{array}{l}\text { Menyampur semua jenis obat } \\
\text { dalam satu wadah }\end{array}$ & $15(15 \%)$ \\
\hline $\begin{array}{l}\text { Memisahkan obat menurut } \\
\text { jenisnya dan memperhatikan cara } \\
\text { penyimpanan di brosur pamflet }\end{array}$ & $78(78 \%)$ \\
\hline $\begin{array}{l}\text { Disimpan pada tempat yang } \\
\text { terpapar sinar matahari }\end{array}$ & $2(2 \%)$ \\
\hline Tidak tahu & $0(0 \%)$ \\
\hline $\begin{array}{c}\text { Pembuangan Obat Nyeri dan Demam } \\
\text { Dibuang langsung di tempat }\end{array}$ & $71(71 \%)$ \\
\hline
\end{tabular}




\begin{tabular}{lc}
\hline sampah & $1(1 \%)$ \\
Dibuang di wastafel & $26(26 \%)$ \\
Memisahkan antara obat dengan & \\
kemasan lalu dibuang & $2(2 \%)$ \\
Dibakar & $0(0 \%)$ \\
Tidak Tahu & \\
\hline Indikasi Obat Nyeri & \\
Sakit gigi & $7(7 \%)$ \\
Nyeri punggung & $61(61 \%)$ \\
Sakit kepala & $19(19 \%)$ \\
Nyeri yang lain & $11(11 \%)$ \\
Tidak tahu & $2(2 \%)$ \\
\hline Indikasi Obat Demam & \\
Suhu demam $>37^{\circ} \mathrm{C}$ & $22(22 \%)$ \\
Suhu demam $>38^{\circ} \mathrm{C}$ & $43(43 \%)$ \\
Suhu demam $>39^{\circ} \mathrm{C}$ & $17(17 \%)$ \\
Suhu demam $>40^{\circ} \mathrm{C}$ & $9(9 \%)$ \\
Tidak tahu & $9(9 \%)$ \\
\hline \hline
\end{tabular}

Namun, penggunaan parasetamol secara sering (didefinisikan penggunaan sehari-hari) pada akhir kehamilan dapat dikaitkan dengan peningkatan risiko sesak nafas yang persisten pada bayi yang dapat bertahan hingga masa kanak-kanak. Para penulis merekomendasikan bahwa parasetamol harus tetap menjadi analgesik pilihan dalam kehamilan (Sweetman, 2009).

Pengobatan yang dilakukan ibu hamil ketika merasakan nyeri paling banyak dilakukan adalah pergi ke rumah sakit/dokter yakni dengan persentase $49 \% \quad(n=49)$. Penggunaan obat analgesik dan antipiretik untuk ibu hamil harus berkonsultasi pada dokter terlebih dahulu untuk menghindari efek ke janin. Obat analgesik dan antipiretik yang dipilih juga harus berpedoman pada kategori obat yang aman untuk ibu hamil menurut FDA. Frekuensi penggunaan obat tergantung pada obat analgesik dan antipiretik yang digunakan dan tujuan terapi (Katzung, 2018).

Pengobatan yang paling banyak dilakukan ibu hamil ketika merasakan demam adalah pergi ke dokter dengan persentase 53\% $\quad(n=53)$. Perubahan fungsi kekebalan selama kehamilan mengubah kerentanan wanita hamil terhadap tingkat keparahan penyakit tertentu (Jamieson et al., 2006). Penatalaksanaan demam bertujuan untuk merendahkan suhu tubuh yang terlalu tinggi, bukan untuk menghilangkan demam. Penatalaksanaan demam dapat dibagi menjadi dua garis besar yaitu non farmakologi dan farmakologi. Akan tetapi, diperlukan penanganan demam secara langsung oleh dokter apabila penderita dengan suhu tubuh $>40,5^{\circ} \mathrm{C}$ dan demam dengan suhu yang tidak turun dalam 48-72 jam (Kaneshiro and Zieve, 2010).

Demam yang berlangsung selama 3 hari atau lebih mengindikasikan ibu hamil mengalami infeksi. Infeksi bisa bersifat ringan (batuk pilek) atau yang bersifat lebih parah (pneumonia, malaria, tuberculosis, typhoid fever, pyelonephritis, dan lainnya) (Jefferey dan Lahra, 2009). Jika ibu hamil hanya mengalami infeksi biasa (batuk pilek) bisa ditanggulangi dengan pengobatan alternatif menggunakan tanaman herbal yaitu bawang putih (sebagai antibiotik alamiah) (Salima, 2014). Durasi demam secara linier dikaitkan dengan hasil yang buruk pada janin. Penyebab demam yang berbeda juga memiliki efek berbeda pada hasil ibu dan janin. Oleh karena itu disarankan bahwa demam selama kehamilan perlu segera diselidiki dan diobati untuk mendapatkan hasil yang lebih baik (More, 2017).

Ibu hamil membeli obat antinyeri dan antidemam paling banyak di apotek dengan persentase $98 \% \quad(n=98)$ ibu hamil. Menurut BPOM RI (2014), obat digolongkan menjadi beberapa golongan yaitu obat bebas, obat bebas terbatas, obat wajib apotek, obat keras, obat narkotika, dan psikotropika. Obat keras, obat wajib apotek, obat narkotika, dan psikotropika hanya dapat diperoleh di apotek. Obat bebas dan obat bebas terbatas merupakan obat yang dapat dijual bebas tanpa resep dokter, sehingga obat bebas dan obat bebas terbatas tidak hanya dapat diperoleh di apotek melainkan di toko-toko yang menjual obat. Namun, meskipun ibu hamil dapat memperoleh obat bebas di supermarket atau toko-toko yang menjual obat, penggunaan obat harus diperhatikan. Kesalahan pemilihan dan penggunaan obat dapat menyebabkan risiko fatal bagi ibu dan bayinya. Pemahaman ibu hamil merupakan salah satu faktor penting dalam pencegahan efek teratogenik yang ditimbulkan oleh obat-obatan. Menurut Menteri Kesehatan (2004), apabila ibu hamil membeli obat di apotek, apoteker akan memberikan informasi obat yang benar, memberikan konseling tentang sediaan farmasi, pengobatan dan perbekalan kesehatan lainnya, sehingga ibu hamil terhindar dari bahaya penyalahgunaan atau penggunaan salah sediaan farmasi atau perbekalan kesehatan lainnya.

Ibu hamil terbanyak memilih menyimpan obat dengan memisahkan obat menurut jenisnya dan memperhatikan cara penyimpanan di brosur pamflet dengan persentase sebanyak $78 \%$ $(n=78)$. Penyimpanan obat yang baik yaitu baca aturan penyimpanan obat pada kemasan; jauhkan dari jangkauan anak; jauhkan dari sinar matahari langsung/ lembab/suhu tinggi dan sebagainya; simpan dalam kemasan asli dan dengan etiket yang masih lengkap; periksa tanggal kedaluwarsa dan kondisi obat, dan kunci almari penyimpanan obat (Depkes RI, 
2008). Cara penyimpanan obat oleh ibu hamil sudah tepat dilakukan.

Ibu hamil dengan persentase $71 \% \quad(n=71)$ membuang obat langsung di tempat sampah. Hal ini kurang benar dipraktikkan. Obat yang sudah kedaluwarsa seharusnya di buang dengan terlebih dahulu melepaskan etiket obat dan menutup botol kemudian dibuang; kapsul, tablet atau bentuk padat lain, menghancurkan dahulu dan mencampur obat tersebut dengan memasukkan ke plastik dan membuang ke tempat sampah; cairan dibuang pada kloset, kecuali antibiotika yang harus dibuang bersama wadahnya dengan menghilangkan labelnya, dan untuk kemasan boks, dus, dan tube terlebih dahulu digunting lalu dibuang (Depkes RI, 2008).

Keluhan nyeri yang paling sering dialami oleh ibu hamil adalah nyeri punggung dengan persentase $61 \% \quad(n=61)$ ibu hamil. Seiring pembesaran uterus dan penambahan berat badan pada kehamilan, maka pusat gravitasi berpindah ke depan sehingga ibu hamil harus menyesuaikan posisi berdirinya. Perubahan tubuh yang tidak tepat akan memaksa peregangan tambahan dan kelelahan pada tubuh terutama pada daerah punggung belakang, sehingga ibu hamil sering mengalami nyeri punggung (Fatmawati, 2017). Pada ibu hamil sering muncul beberapa keluhan seperti konstipasi, batuk, diare, hemoroid (ambeien), alergi, sakit perut, nyeri (sakit kepala, sakit gigi), dan keputihan (Byrom et al., 2009).

Sejumlah $43 \% \quad(n=43)$ ibu hamil menganggap dirinya demam apabila termometer menunjukkan suhu $>38^{\circ} \mathrm{C}$. Suhu normal tubuh adalah $36,5-37,5^{\circ} \mathrm{C}$. Dikatakan demam apabila suhu tubuh diatas normal. Ibu hamil dapat dikatakan demam jika panas tubuh lebih dari $38^{\circ} \mathrm{C}$ (Kukus et al., 2009).

\section{Pengaruh Usia dengan Tingkat Pengetahuan Ibu Hamil}

Analisis regresi linier digunakan untuk mengetahui pengaruh variabel usia ibu hamil terhadap pengetahuan ibu hamil tentang obat analgesik dan antipiretik pada saat kehamilan. Berdasarkan uji ANOVA diperoleh p-value sebesar 0,373 dimana p-value lebih besar daripada taraf signifikansi $(\alpha=5 \%)$. Sehingga dapat disimpulkan bahwa usia tidak mempengaruhi tingkat pengetahuan ibu hamil tentang obat analgesik dan antipiretik. Hal ini sesuai dengan hasil penelitian pengaruh usia, pendidikan, dan pengetahuan terhadap konsumsi tablet tambah darah pada ibu hamil di Puskesmas Maron, Kabupaten Probolinggo (Shofiana et al., 2018) yang menyatakan hasil analisis menunjukkan tidak ada pengaruh usia ibu terhadap konsumsi tablet $(\mathrm{p}=0,914>0,05)$ terhadap konsumsi tablet tambah darah.

Ibu hamil yang memiliki usia lebih tua belum tentu memiliki tingkat konsumsi tablet tinggi. Begitu pula sebaliknya, ibu hamil yang berusia lebih muda belum tentu memiliki tingkat konsumsi tablet yang rendah. Pada ibu hamil di wilayah Puskesmas Maron, usia bukanlah variabel yang berpengaruh terhadap konsumsi tablet tambah darah. Ibu hamil berusia lebih tua belum tentu memiliki tingkat konsumsi tablet tambah darah tinggi, namun sebaliknya ibu hamil berusia lebih muda juga belum tentu memiliki tingkat konsumsi tablet tambah darah rendah (Shofiana et al., 2018).

\section{Hubungan Pendidikan dengan Tingkat Pengetahuan Ibu Hamil}

Analisis Fisher eksak digunakan untuk mengetahui pengaruh variabel pendidikan ibu hamil terhadap pengetahuan ibu hamil tentang obat analgesik dan antipiretik pada saat kehamilan. Fisher eksak yang digunakan adalah tabel dengan rumus $4 \times 4$ yang dapat dilihat pada tabel 7.

Tabel 7. Hubungan pendidikan dengan tingkat pengetahuan ibu hamil

\begin{tabular}{ccccc}
\hline \hline Hubungan & Rendah & Sedang & Tinggi & $\begin{array}{c}\text { Sangat } \\
\text { Tinggi }\end{array}$ \\
\hline SD & 0 & 1 & 0 & 5 \\
\hline SMP & 0 & 0 & 11 & 2 \\
\hline SMA/SMK & 0 & 27 & 20 & 0 \\
\hline D1/D3/S1/S2 & 21 & 13 & 0 & 0 \\
\hline \hline
\end{tabular}

Ket : Fisher eksak nilai p-value $=0,469$

Uji Fisher diperoleh p-value sebesar 0,469 dimana lebih besar dari taraf signifikansi $(\alpha=5 \%)$. Sehingga dapat disimpulkan bahwa tidak terdapat pengaruh antar tingkat pendidikan ibu hamil terhadap pengetahuan ibu hamil tentang obat analgesik dan antipiretik. Hal ini sesuai dengan hasil penelitian pengaruh usia, pendidikan, dan pengetahuan terhadap konsumsi tablet tambah darah pada ibu hamil di Puskesmas Maron, Kabupaten Probolinggo (Shofiana et al., 2018) yang menyatakan hasil analisis menunjukkan tidak ada pengaruh variabel pendidikan ibu terhadap konsumsi tablet $(\mathrm{p}=0,419>0,05)$ terhadap konsumsi tablet tambah darah.

Pendidikan ibu tidak ada pengaruh terhadap konsumsi tablet tambah darah, bukan berarti jika pendidikan yang tinggi maka akan mengkonsumsi tablet tambah darah secara rutin. Begitu pula sebaliknya, apabila pendidikan yang 
rendah, maka bukan berarti rutin mengkonsumsi tablet ataupun tidak rutin mengkonsumsi tablet.

Berdasarkan uraian tersebut, apabila ibu hamil memiliki lebih banyak pengalaman serta terkait dengan kesehatan, lebih memiliki kematangan jiwa dan emosi dalam mengambil keputusan untuk mengkonsumsi tablet setiap hari (Shofiana et al., 2018).

\section{KESIMPULAN}

Pengetahuan obat analgesik dan antipiretik pada ibu hamil di wilayah Surabaya Timur dilihat berdasarkan hasil rata-rata skor total yaitu 6,3. Hasil skoring tersebut memberikan kesimpulan bahwa ibu hamil kurang paham tentang obat analgesik dan antipiretik yang aman dikonsumsi selama kehamilan. Selain itu, hasil penelitian menunjukkan penggunaan obat analgesik dan antipiretik pada ibu hamil masih tergolong kurang tepat. Sedangkan, dari hasil pvalue meliputi pengujian ANOVA, usia tidak berpengaruh pada pengetahuan ibu hamil tentang obat analgesik dan antipiretik. Selain itu, uji Fisher eksak juga membuktikan bahwa pendidikan tidak berpengaruh pada pengetahuan ibu hamil tentang obat analgesik dan antipiretik.

Hasil penelitian ini memberikan kesimpulan bahwa diperlukan adanya solusi untuk meningkatkan pengetahuan ibu hamil mengenai obat analgesik dan antipiretik yang aman dikonsumsi selama kehamilan. Salah satu yang dapat dilakukan adalah dengan memberikan edukasi yang tepat sasaran. Edukasi yang dilakukan juga dapat ditunjang dengan menggunakan media promosi kesehatan terkait obat analgesik dan antipiretik pada ibu hamil, mengingat beberapa obat analgesik dan antipiretik ada yang menyebabkan efek buruk pada janin.

\section{UCAPAN TERIMAKASIH}

Penulis mengucapkan terima kasih kepada dosen pembimbing kami Ibu Dr. apt. Yunita Nita. S.Si., M.Pharm. dan pihak puskesmas yang terkait serta seluruh pihak lain yang sudah berpartisipasi pada penelitian ini.

\section{DAFTAR PUSTAKA}

Aprilia RM, Artini IGA 2017, 'Gambaran pola pengobatan dan tingkat pengetahuan mengenai penggunaan obat selama kehamilan di puskesmas Denpasar Utara II Bali', E-Jurnal Medika, 6(7), pp. 1-6.
Badan Pengawas Obat dan Makanan 2014, Informatorium Obat Nasional Indonesia Cetakan Tahun 2017, BPOM RI, Jakarta.

Briggs GG, Freeman RK, Yaffe SJ 2015, Drug in Pregnancy and Lactation 10th ed, Wolters Kluwer Health, Philadelphia.

Byrom S, Cooper J, Edington A, Elliman D, Gutteridge K, Henry S, Shakespeare J, Scholefield H 2009, The Pregnancy Book, COI for the Department of Health, London.

Departemen Kesehatan RI 2004, Keputusan Menteri Kesehatan Republik Indonesia No 1027/MENKES/SK/IX/2004 tentang Standar Pelayanan Kefarmasian di Apotek, Menteri Kesehatan Republik Indonesia, Jakarta.

Departemen Kesehatan RI 2006, Pedoman Pelayanan Farmasi untuk Ibu Hamil dan Menyusui, Direktorat Bina Farmasi Komunitas dan Klinik Departemen Kesehatan RI, Jakarta.

Departemen Kesehatan RI 2008, Modul I, Materi Pelatihan Peningkatan Pengetahuan dan Keterampilan Memilih Obat Bagi Tenaga Kesehatan, Departemen Kesehatan RI, Jakarta.

Drugs.com 2019, FDA Pregnancy Categories, viewed $21 \quad$ September 2019, https://www.drugs.com/pregnancycategories.html

Fatmawati FF 2017, 'Upaya Pemenuhan Rasa Nyaman Pada Ibu Hamil Trimester III Dengan Nyeri Punggung' Skripsi, Universitas Muhammadiyah Surakarta. Surakarta.

Food and Drug Administration 2015, FDA Drug Safety Communications: Possible Risks of Pain Medicine Use During Pregnancy, viewed $23 \quad$ Agustus 2019, https://www.fda.gov/media/90209/download

Le Gouez A, Benachi A, Mercier FJ 2016, 'Fever and pregnancy', Anaesthesia Critical Care and Pain Medicine, 35(1), pp. S5-S12.

Jamieson DJ, Theiler RN, Rasmussen SA 2006, 'Emerging infections and pregnancy', Emerging Infectious Diseases, 12(11), pp. 1638-1643.

Jeffery HE, Lahra MM 2007, 'The impact of infection during pregnancy on the mother and baby' Fetal and Neonatal Pathology, pp. 379-423.

Kaneshiro NK, Zieve D 2010, Fever, viewed 10 Oktober 2019, http://www.nlm.nih.gov/medlineplus/ency/ar ticle/000980.htm

Katzung B 2018, Basic and Clinical Pharmacology ed. $14^{\text {th }}$, USA.

Kukus Y, Supit W, Lintong F 2009, 'Suhu tubuh: homeostasis dan efek terhadap 
kinerja tubuh manusia', Jurnal Biomedik, 1(2), pp. 107-118.

Mafikasari A, Kartikasari RA 2015, 'Posisi tidur dengan kejadian back pain (nyeri punggung) pada ibu hamil trimester III', Surya, 7(2), pp. 26.

Malhotra S, Khanna S 2016, 'Safety of analgesics in pregnancy', International Journal Of Obstetrics and Gynaecology Research (IJOGR), 3(1), pp. 208-209.

More VS 2017, 'Fever in pregnancy and its maternal and fetal outcomes', International Journal of Reproduction, Contraception, Obstetrics and Gynecology, 6(12), pp. 5523.

Payadnya IPAA, Jayantika IGANT 2018, Panduan Penelitian Eksperimen Beserta Analisis Statistik dengan SPSS. Cetakan Pertama, Deepublish., Yogyakarta.

Salima J 2014, 'Antibacterial activity of garlic (Allium sativum 1.) on multi-drug resistant, $J$ Majority, 4(2), pp. 30-39.
Sass L, Urhoj SK, Kjærgaard J, Dreier JW, Strandberg-Larsen K, Andersen 2017, 'Fever in pregnancy and the risk of congenital malformations: a cohort study', BMC Pregnancy Childbirth, 17, pp. 413.

Shofiana FI, Widari D, Sumarmi S 2018, 'Pengaruh usia, pendidikan dan pengetahuan terhadap konsumsi tablet tambah darah pada ibu hamil di puskesmas Maron, kabupaten Probolinggo, E-journal Universitas Airlangga, 2(4), pp. 356-358

Susanti NN 2008, Psikologi Kehamilan, EGC, Jakarta.

Sweetman SC 2009, Martindale $36^{\text {th }}$ The Complete Drug Reference, Pharmaceutical Press, London.

Walpole RERH, Myers SL, Myers, Ye K 2012, Probability and Statistics for Engineers and Scientics Edisi 9, Pearson Education, Amerika 